\title{
Whither the Common Law Derivative Action?
}

\author{
Ji Lian Yap*
}

\begin{abstract}
The common law derivative action was developed as a result of decades of case law in common law jurisdictions. Hong Kong and Singapore continue to retain the common law derivative action within their respective legal frameworks, despite both having enacted statutory derivative actions. This paper considers the situations in which the common law derivative action continues to have practical application in each of these jurisdictions. It then considers whether the common law derivative action should be abolished in these jurisdictions, and if so, what consequential changes should be made to the statutory derivative action framework concurrent with this proposed abolition.
\end{abstract}

Keywords: derivative action, minority shareholders, company law, common law, Hong Kong, Singapore

\section{Introduction}

This paper considers the common law derivative action by asking several related questions. First, to what extent does it remain useful and relevant, given that many jurisdictions have replaced it with a statutory derivative action? This question will be considered in the context of Hong Kong and Singapore, both of which have retained the common law derivative action within their legal framework concurrent with statutory derivative actions. The next question is whether the common law derivative action should be abolished in these jurisdictions. The paper will also consider what changes should be made to the statutory derivative action regime in Hong Kong and Singapore, if the common law derivative action is indeed abolished in these jurisdictions, in order to ensure sufficient protection for minority shareholders and an effective corporate governance regime.

\section{The Common Law Derivative Action}

Where the directors have breached their fiduciary duties to a company, but have the support of a majority of the members, or worse, themselves constitute a majority of the members, the company is most

* Ji Lian Yap, Teaching Consultant, Faculty of Law, The University of Hong Kong. LLB (National University of Singapore) (Dean's List), LLM (Cambridge University). E-mail: jilyap@hku.hk. 
unlikely to take action against the wrongdoing directors. However, as a breach of fiduciary duty is a wrong to the company, it is the company who is the proper plaintiff. Since the company is a separate entity from its members, generally only the company (and not its members) can sue to enforce a company's rights. ${ }^{1}$

However, various exceptions to this principle have evolved over time, one of which is the development of the common law derivative action. The common law derivative action seeks to empower a minority shareholder to take action on behalf of the company, in circumstances where the wrongdoing director is in control of the company and thus resulting in the company not taking action to redress the wrong done to it.

In order for a common law derivative action to be brought, a fraud on the minority must be shown. ${ }^{2}$ While there is no comprehensive and definitive statement on the meaning of a fraud on the minority, it has been suggested that the following must be shown in order for a fraud on the minority to be established. ${ }^{3}$ First, that the majority shareholders obtained a benefit; next, that this benefit was obtained at the expense of the company or that some detriment was caused to the company; and third, that the majority shareholders used their controlling power to prevent an action being brought against them by the company.

In many common law jurisdictions, provisions for the creation of a statutory derivative action have been enacted. The primary impetus for the enactment of statutory derivative action regimes was a desire to clarify the uncertainty and confusion that had arisen from decades of case law from which the common law derivative action had evolved. For example in the United Kingdom, the Law Commission described the rule in Foss v Harbottle ${ }^{4}$ and the exceptions thereto as 'inflexible and outmoded', ${ }^{5}$ noting that many of the principles were found in old cases, and criticizing the uncertainties involved in ascertaining the notion of control of the company by the wrongdoer. $^{6}$ These sentiments in turn led the common law derivative action to be replaced by the statutory derivative action in jurisdictions such as the United Kingdom, Canada, Australia and New Zealand.

Hong Kong and Singapore have also developed their own statutory derivative action models, but the common law derivative action is still preserved in these jurisdictions and exists concurrently with the statutory action. Given that both Hong Kong and Singapore already have

1 This is the Proper Plaintiff Rule, otherwise known as the rule in Foss v Harbottle (1843) 2 Hare 461.

2 Prudential Assurance Co Ltd v Newman Industries Ltd (No. 2) [1982] Ch 204.

3 L.L. Lan, Walter Woon on Company Law, 3rd edn (Sweet \& Maxwell: London, 2005) 357.

4 Foss v Harbottle (1843) 2 Hare 461.

5 Law Commission, Shareholder Remedies (Consultation Paper No. 142 1996) at para. 14.1.

6 Ibid. at para. 14.2 . 
a statutory derivative action within their respective legal frameworks, to what extent is the common law derivative action still useful and relevant in these jurisdictions? The next section seeks to address this question.

\section{The Common Law Derivative Action in Hong Kong}

\section{i. The Continued Relevance of the Common Law Derivative Action in Hong Kong}

Section 168BC(4) of the Hong Kong Companies Ordinance clarifies that the provisions relating to the statutory derivative actions shall not affect any common law right of a member of a specified corporation to bring proceedings on behalf of the specified corporation. It is thus clear that the common law derivative action remains within the Hong Kong legal framework. However, a shareholder may not be allowed to commence both a statutory derivative action and a common law derivative action on the same cause of action or matter. ${ }^{7}$

The statutory derivative action generally appears to offer a better remedy to minority shareholders than common law derivative action because the concept of misfeasance is more clearly defined ${ }^{8}$ than the vague and complex concept of fraud on the minority that is required in order to bring a common law derivative action. Under what circumstances then might an aggrieved minority shareholder still choose to base their claim on the common law derivative action rather than the statutory derivative action?

One such circumstance is when a multiple derivative action is sought to be taken. A derivative action usually involves a straightforward situation of a member of a company taking action on behalf of the company to redress a wrong done to the company. ${ }^{9}$ This may be described as a simple derivative action. However, a multiple derivative action is more complex. It contemplates a situation where the party seeking to sue is not a shareholder of the company in which the cause of action is vested, but is instead a shareholder of its holding company. The question in deciding whether a multiple derivative action may be granted was succinctly phrased by Lord Millett, ${ }^{10}$ in framing the question as "whether a ... derivative action may be brought by a person who is not a shareholder in the company in which the cause of

7 Companies Ordinance, s. 168BE.

8 'Misfeasance' is defined in section 168BB(2) of the Companies Ordinance as meaning fraud, negligence, default in compliance with any enactment or rule of law, or breach of duty.

9 This is the situation contemplated in section 260(1) of the United Kingdom Companies Act 2006, which describes a 'derivative claim' as one involving a member of a company taking proceedings in respect of a cause of action vested in the company and seeking relief on behalf of the company.

10 In his capacity as Non-Permanent Judge of the Court of Final Appeal of Hong Kong. 
action is vested and on behalf of which the action is brought but a shareholder in its parent or ultimate holding company'. ${ }^{11}$

In considering this issue in relation to the statutory derivative action in the United Kingdom, the Law Commission has elaborated on the nomenclature as follows:

Logically an action by a shareholder of a parent company on behalf of a subsidiary is called a 'double' derivative action and, if on behalf of a 'second tier' subsidiary, it would be called a 'triple' derivative action. It is therefore easier to refer to all these actions as 'multiple' derivative actions. ${ }^{12}$

In such situations, if the majority shareholders of the holding company are in support of the wrongdoing directors, or are in fact the wrongdoing directors themselves, it would be apparent that the company in which the cause of action is vested would be most unlikely to take action against the wrongdoing directors. The minority shareholders of the holding company would thus face the same dilemma as in the case of a simple derivative action as described above. There is no practical difference in the situation of a minority shareholder in the respective simple and multiple derivative action scenarios. In both cases, if the derivative action is unavailable, the minority shareholder would not be able to claim on the company's behalf against the wrongdoing directors.

However, in Hong Kong, it is expressly clear that only a member of the company may apply to bring a statutory derivative action. ${ }^{13}$ It would follow from this that multiple derivative actions are not allowed under the regime in Hong Kong for the statutory derivative action.

In contrast, in the recent case of Waddington Limited v Chan Chun Hoo Thomas, $^{14}$ the Court of Final Appeal held that multiple derivative actions were allowed in respect of the common law derivative action. As Lord Millett (in his capacity as Non-Permanent Judge of the Court of Final Appeal) put it:

The very same reasons which justify the single derivative action also justify the multiple derivative action. To put the same point another way, if wrongdoers must not be allowed to defraud a parent company with impunity, they must not be allowed to defraud its subsidiary with impunity. ${ }^{15}$

From this brief survey, it can be seen that while multiple derivative actions are allowed under the common law, the Hong Kong statutory derivative action regime appears to draw an artificial distinction between simple and multiple derivative actions, allowing the former but

11 Waddington Limited v Chan Chun Hoo Thomas [2008] HKEC 1498 at para. 33.

12 See Law Commission, above n. 5 at para. 16.51.

13 Section 168BC(1) of the Companies Ordinance states that a member of a specified corporation may, with the leave of the court granted under section 168BC(3), bring proceedings before the court on behalf of the specified corporation.

14 Above n. 11.

15 Above n. 11 at para. 75. 
effectively disallowing the latter. A shareholder faced with a need to mount a multiple derivative action in Hong Kong would thus have to pursue a common law derivative action.

As a side point, the alternative remedy of an unfair prejudice claim under section 168A of the Companies Ordinance ${ }^{16}$ must be considered. Section 168A of the Companies Ordinance allows a member of a company who complains that the affairs of the specified corporation are being or have been conducted in a manner unfairly prejudicial to the interests of the members to make an application to the court. In Re Citybranch Ltd $^{17}$ it was held that the affairs of a subsidiary could also be regarded as the affairs of a parent company for the purposes of an unfair prejudice claim. A wide range of remedies are available pursuant to section 168A(2), including the making of an order that such proceedings as the court may think fit be in the name of the specified corporation against such person and on such terms as the court may so order. ${ }^{18}$ However, Lord Millett has expressed doubt as to whether a multiple derivative action may be ordered pursuant to that section. ${ }^{19}$ It therefore appears that the rather roundabout method of pursuing a derivative action by way of the unfair prejudice provisions would not in any event be available to an aggrieved minority shareholder seeking to pursue a multiple derivative claim in Hong Kong.

\section{ii. The Proposal to Abolish the Common Law Derivative Action in Hong Kong and Recommended Consequential Changes to the Statutory Derivative Action Regime}

The concurrent existence of the common law and statutory derivative actions within the Hong Kong framework has been widely criticized. In Waddington Limited v Chan Chun Hoo Thomas, ${ }^{20} \mathrm{Mr}$ Justice Ribeiro described that co-existence of both the statutory and common law derivative action regimes as 'a source of confusion and complication', ${ }^{21}$ and suggested that the 'statutory regime . . . replace the common law derivative action altogether' ${ }^{22}$ The call to dispense with the present concurrent regime has also been heard in various academic writings. $^{23}$

The original rationale for preserving the common law derivative action in Hong Kong appears to have been to provide a remedy for

16 Section 168A of the Hong Kong Companies Ordinance broadly reflects section 994 of the Companies Act 2006 in the United Kingdom.

17 Re Citybranch Ltd [2005] 1 WLR 3505.

18 Companies Ordinance, s. 168A(2)(a)(ii).

19 Above n. 11 at para. 78.

20 Above n. 11.

21 Above n. 11 at para. 32.

22 Above n. 11 at para. 32

23 P. Von Nessen, S. Goo and C.K. Low, 'The statutory derivative action: Now showing near you' (2008) 7 JBL 627-61 and R. Cheung, 'The New Statutory Derivative Action in Hong Kong: A Critical Examination: Part 2' (2008) 29(10) Comp. Law 313-20. 
members of companies that are incorporated overseas but controlled by Hong Kong residents. ${ }^{24}$ However, it has been noted that the statutory derivative action regime in Hong Kong applies to non-Hong Kong companies, ${ }^{25}$ thus removing the basis for this original justification.

If the common law derivative action is abolished in Hong Kong, what consequential changes should be made to the statutory derivative action regime? One suggestion is that the statutory derivative action regime should be amended to allow for multiple derivative actions. ${ }^{26}$ To abolish the common law derivative action and yet not to take this important consequential step would result in a loophole in remedies available to minority shareholders, and pose a gap in the corporate governance framework in Hong Kong. Conversely, as Lord Millett observed, 'once the legislation is extended to cover multiple derivative actions, the continued existence of two parallel regimes will serve no discernible purpose'.$^{27}$

However, in this, as in most other areas of law reform, the devil is in the detail. The question is precisely how provision should be made under Hong Kong law to allow for multiple derivative actions.

It is interesting to note that under Part 11 of the United Kingdom Companies Act 2006, multiple derivative actions are similarly not allowed. ${ }^{28}$ There have been calls for the Companies Act 2006 to be amended to allow for multiple derivative actions. ${ }^{29}$ The following discussion might thus also be of interest to those exploring similar legislative amendment in the United Kingdom.

A number of other common law jurisdictions have paved the way to leave room for the possibility of multiple derivative actions within their respective statutory frameworks, and a consideration of some of these may provide a useful reference point for possible legislative amendments.

The statutory derivative action in Singapore is available to members and 'any other person who in the discretion of the Court is a proper person to make an application'. ${ }^{30}$ It has been suggested that shareholders of a related company may fall within the ambit of the latter category. ${ }^{31}$ Similarly in Canada, a derivative action can be

24 Financial Services Branch, Consultation Paper on Statutory Derivative Action in the Companies (Amendment) Bill 2003.

25 P. Kwan, Hong Kong Corporate Law (LexisNexis: Hong Kong, 2006) 1146.

26 See Cheung, above n. 23.

27 Above n. 11 at para. 55.

28 Section 260(1) of the Companies Act 2006 defines a derivative claim as one taken out by a member of a company. Given that the statutory derivative action replaces the common law derivative action in the United Kingdom, the minority shareholder of the holding company would not be able to take a derivative action in respect of the cause of action vested in the subsidiary company.

29 A. Reisberg, Derivative Actions and Corporate Governance (Oxford University Press: Oxford, 2007) 202.

30 Singapore Companies Act (Cap. 50), s. 216A(1).

31 See Lan, above n. 3 at 364. 
brought by (among others) a registered holder of a security of a corporation, or any other person who, in the discretion of a court, is a proper person ${ }^{32}$ to make such an application. ${ }^{33}$ However, it is suggested that the nebulous idea of the 'proper person' is best avoided, as this would result in uncertainty as to who would fall within its scope. Such uncertainty as to which parties may commence a statutory derivative action should be avoided in this already complicated area of law.

In contrast, section 236 of the Australian Corporations Act 2001 lists those entitled to bring a statutory derivative action on behalf of a company as including not only members of the company but also members of a related body corporate. ${ }^{34}$ It is clear that there is scope for multiple derivative actions to be pursued under the Australian framework. Similarly in New Zealand, the court may, on the application of a shareholder or director of a company, grant leave to that shareholder or director to bring proceedings in the name and on behalf of the company or any related company. ${ }^{35}$ A related company is comprehensively defined ${ }^{36}$ and the New Zealand provisions would thus provide scope for multiple derivative actions.

It would seem that the statutory formulations in Australia and New Zealand $^{37}$ are clearer than the Canadian and Singaporean formulation, in that they avoid the nebulous idea of the 'proper person' in favour of the defined and objective concept of a 'related body corporate' or a 'related company' respectively. This would promote greater clarity as to which parties may commence a statutory derivative

32 In Re Daon Development Corporation (1984) 54 BCLR 235, it was stated that 'proper persons' were those who had 'a direct financial interest in how the company is being managed and are in a position-somewhat analogous to minority shareholders-where they have no legal right to influence or change what they see to be abuses of management or conduct contrary to the company's interest'.

33 Canadian Business Corporations Act, s. 238.

34 Section 50 of the Corporations Act 2001 clarifies that where a body corporate is (a) a holding company of another body corporate; or (b) a subsidiary of another body corporate; or (c) a subsidiary of a holding company of another body corporate; the first-mentioned body and the other body are related to each other.

35 New Zealand Companies Act 1993, s. 165(1).

36 Section 2(3) of the New Zealand Companies Act 1993 states that a company is related to another company if (a) The other company is its holding company or subsidiary; or (b) More than half of the issued shares of the company, other than shares that carry no right to participate beyond a specified amount in a distribution of either profits or capital, is held by the other company and companies related to that other company (whether directly or indirectly, but other than in a fiduciary capacity); or (c) More than half of the issued shares, other than shares that carry no right to participate beyond a specified amount in a distribution of either profits or capital, of each of them is held by members of the other (whether directly or indirectly, but other than in a fiduciary capacity); or (d) The businesses of the companies have been so carried on that the separate business of each company, or a substantial part of it, is not readily identifiable; or (e) There is another company to which both companies are related.'

37 It has been suggested that it would be beneficial for Hong Kong to make a closer examination of the New Zealand provisions: see Cheung, above n. 23. 
action, and avoid further uncertainty in this already complicated area of law.

\section{The Common Law Derivative Action in Singapore}

\section{i. The Continued Relevance of the Common Law Derivative Action in Singapore}

The common law derivative action remains relevant in Singapore, primarily because the statutory derivative action is expressly unavailable to members of listed companies. The statutory derivative action is embodied in sections 216A and 216B of the Singapore Companies Act, and it is provided in section 216A(1) that for the purpose of those sections, a 'company' means a company other than a company that is listed on the securities exchange in Singapore. Members of listed companies thus do not have recourse to the statutory derivative action and would have to rely on the common law to base their derivative claims.

The reasons for not extending the statutory derivative action to members of listed companies were that listed companies are already monitored by the securities exchange and also that disgruntled shareholders of listed companies may simply sell their shares on the stock market, and thus do not require recourse to the statutory derivative action framework. ${ }^{38}$

\section{ii. The Proposal to Abolish the Common Law Derivative Action in Singapore and Suggested Consequential Changes to the Statutory Derivative Action Regime}

The unavailability of the statutory derivative action framework to members of listed companies has been criticized. ${ }^{39}$ With regard to the argument that listed companies are monitored by the securities exchange, it does not follow from this that their minority members do not deserve the benefit of recourse to the statutory derivative action framework. It would seem that the function of a securities exchange is to ensure a vibrant but stable securities trading environment. The work of the securities exchange would be directed to achieving this general public policy objective. ${ }^{40}$ In contrast, the purpose of a derivative action is to enable a minority shareholder to obtain redress on behalf of a company for a wrong done to the company. It is clear that

38 Singapore Parliamentary Reports, Vol. 61 at col. 293, 28 May 1993 as cited in M. Chew, Minority Shareholders' Rights and Remedies, 2nd edn (LexisNexis: Singapore, 2007) 295.

39 See Reisberg, above n. 29 at 178, and Chew, above n. 38 at 296.

40 In the context of the Singapore Exchange, its vision is to build an enduring marketplace, while its mission is to offer a highly trusted securities and derivatives marketplace for capital raising, risk transfer, trading, clearing and settlement, and to serve its stakeholders. This is stated on the website of the Singapore Exchange: www.sgx.com (retrieved 8 June 2009). 
these functions are conceptually separate, the former having an essentially systemic focus, the latter being focused on the rights of a particular company and the grievances of its minority shareholders. Added to this is the pragmatic observation that the ability of regulatory authorities and agencies to monitor management ... is necessarily bound by practical, budgetary and perhaps political constraints' ${ }^{41}$

In respect of the argument that minority shareholders of listed companies may sell their shares in the market and thus do not need recourse to the statutory derivative action framework, it has been pointed out that the wrongdoing may decrease share values, making it unrealistic to expect a minority shareholder to divest themselves of their interest in the market. ${ }^{42}$

A fear that a litigious shareholder owning one share could pursue a derivative action to the prejudice of the local stock market was also expressed. ${ }^{43}$ This is the fear of frivolous applications and hints at opening the floodgates of litigation. However, jurisdictions such as Canada and Australia have all allowed their respective statutory derivative schemes to apply to members of listed companies, and do not appear to have been flooded with such frivolous claims.

It is therefore submitted that the statutory derivative action should be extended to members of listed companies. Once this is done and the existing lacuna in respect of such members is closed, there appears to be little reason to retain the common law derivative action. Instead, Singapore should follow the position in the United Kingdom, Canada, Australia and New Zealand, and abolish the common law derivative action. This would make the legal framework in respect of deriv-

ative actions in Singapore less unwieldy. The development of the derivative action in Singapore would then be solely focused on the statutory route.

\section{Conclusion}

The common law derivative action was developed as a result of decades of case law in common law jurisdictions. However, in many jurisdictions, it has been replaced with the statutory derivative action which has sought to be a more streamlined and less complex tool for the minority shareholder. Nonetheless Hong Kong and Singapore continue to retain the common law derivative action within their respective legal frameworks, despite both already having statutory derivative actions. We have seen that while there are at present situations in which the common law derivative action continues to have

41 See Reisberg, above n. 29 at 179.

42 Ibid. and Chew, above n. 38 at 296.

43 Singapore Parliament Reports, 14 September 1992, Vol. 60 at col. 241 as cited in Chew, above n. 38 at 296. 
practical application in each of these jurisdictions, these do not furnish sufficient justification for the retention of the concurrent statutory and common law derivative action regimes. Instead, it is argued that the common law derivative action should be abolished in both these jurisdictions. However, consequential changes must be made to the statutory derivative action framework in tandem with this proposed abolition, so as to provide minority shareholders with proper protection and to ensure high corporate governance standards in each of these common law jurisdictions. 
Copyright of Common Law World Review is the property of Vathek Publishing Ltd and its content may not be copied or emailed to multiple sites or posted to a listserv without the copyright holder's express written permission. However, users may print, download, or email articles for individual use. 